Original research article

\title{
Genetic association of Tumour necrosis factor alpha, Interleukin-18 and Interleukin 1 beta with the risk of coronary artery disease: A case-control study outcome from Kashmir
}

\author{
Nuzhat Shaheen Khan ${ }^{\mathrm{a}}$, Mohammad Sultan Allai ${ }^{\mathrm{b}}$, Bushra Nissar ${ }^{\mathrm{a}}$, Niyaz Ahmad Naykoo ${ }^{\mathrm{c}}$, \\ Iqra Hameed $^{\mathrm{a}}$, Misbah Majid ${ }^{\mathrm{a}}$, Aaliya Bhat ${ }^{\mathrm{a}}$, Falaque ul Afshan ${ }^{\mathrm{a}}$, Bashir Ahmad Ganai ${ }^{\mathrm{d}, *}$ \\ a University of Kashmir, School of Biological Sciences, Department of Biochemistry, Srinagar, JEK, India \\ ${ }^{\mathrm{b}}$ Sher-I-Kashmir Institute of Medical Sciences, Department of Cardiology, Srinagar, JEK, India \\ c Government of Jammu and Kashmir, Department of Higher Education, Srinagar, JEK, India \\ ${ }^{\mathrm{d}}$ University of Kashmir, Centre of Research for Development, Srinagar, JEK, India
}

\section{A R T I C L E I N F O}

\section{Article history:}

Received 4 June 2017

Received in revised form 27 January 2018

Accepted 20 February 2018

Available online 27 February 2018

\section{Keywords:}

Inflammation

Coronary artery disease

Kashmiri

Polymorphism

Biomarkers

\begin{abstract}
A B S T R A C T
Coronary artery disease (CAD) is a clinical manifestation of atherosclerosis in the arteries supplying myocardium. Inflammation is the cornerstone in the development and progression of atherosclerosis. Amongst the various biomolecules tumour necrosis factor- $\alpha$ (TNF- $\alpha$ ), interleukin-18 (IL-18) and interleukin-1 $\beta$ (IL-1 $\beta$ ) build an inflammatory bionetwork in developing the disease. In this study we investigated the association of TNF- $\alpha$ SNPs [-308G/A (rs1800629), -1031T/C (rs1799964), -863C/A (rs1800630)]; IL-18 [-137G/C (rs187238)] and IL-1 $\beta$ SNPs [+3954C/T (rs1143634), -31C/T (rs1143627), and $-511 \mathrm{C} / \mathrm{T}$ (rs16944)] with coronary artery disease risk in Kashmiri population. A total of 200 cases and 260 controls were recruited in the study. Logistic regression analysis was done to investigate the association between SNPs and CAD risk. In case of TNF- $\alpha$, the $-308 \mathrm{G} / \mathrm{A}-\mathrm{A} / \mathrm{A}$ and $-863 \mathrm{~A} / \mathrm{A}$ showed an association with disease while $-1031 \mathrm{~T} / \mathrm{C}$ was found to have an inverse relation. The IL-18-137G/C showed no statistically significant difference between controls and cases. For IL$1 \beta$ the $+3954 \mathrm{C} / \mathrm{T}$ and $-31 \mathrm{C} / \mathrm{T}$ SNP variants showed no disease association while $-511 \mathrm{~T} / \mathrm{T}$ showed significant association. Haplotypic analysis revealed the haplotype ATCGCC and GTACCTC to be associated with CAD risk and GTCGTTT, in particular, showing a profound association. Overall, our study suggests that TNF- $\alpha$ and IL-1 $\beta$ promoter polymorphisms may act as genetic risk factors in developing the coronary artery disease.
\end{abstract}

(c) 2018 Faculty of Health and Social Sciences, University of South Bohemia in Ceske Budejovice. Published by Elsevier Sp. z o.o. All rights reserved.

\section{Introduction}

Coronary heart disease is the leading cause of death worldwide, accounts for over seven million deaths annually. In Indian Asians, a fifth of all the global deaths are due to coronary heart disease (CHD) (Lozano et al., 2012). A cross sectional study conducted in the state of Jammu and Kashmir shows the prevalence of CAD to be $7.54 \%$ (rural $-6.7 \%$, urban $-8.37 \%$, males $-7.88 \%$, females $-6.63 \%$ )

\footnotetext{
Abbreviations: CAD, coronary artery disease; TNF- $\alpha$, tumour necrosis factor alpha; IL-18, interleukin-18; IL-1 $\beta$, interleukin 1 beta; bp, base pair.

* Author for correspondence: University of Kashmir, Centre of Research for Development, Hazratbal, Srinagar, 190006 Jammu and Kashmir, India.

E-mail addresses: ganaiba@kashmiruniversity.ac.in, bbcganai@gmail.com (B.A. Ganai).
}

(Kamili et al., 2007). Kashmir lies in the north of India and is more predisposed to developing CAD because of the ongoing lifestyle modifications and the increased exposure to traumatic and distressful conditions (Dharmender et al., 2012). The eight common risk factors that explain more than $90 \%$ of incident acute myocardial infarctions in South Asian and Indian patients are dyslipidemia, smoking, hypertension, Type-2 diabetes, central obesity, physical inactivity, low fruits and vegetable intake, and psychosocial stress (Joshi et al., 2007). Amongst them, diabetes is an independent and a major risk factor for CAD (Antoniades et al., 2004). The increased amount of reactive oxygen species and hyperglycemia in diabetes causes LDL modification, endothelial damage and dysfunction.

Coronary artery disease is a polygenic and multifactorial disease of the arteries supplying blood to the muscles of heart. It is characterized by loss of elasticity and partial or complete 
decrease in the lumen of coronary arteries. There is impairment in the myocardial blood flow resulting in ischemia and myocardial infarction. Coronary artery disease is now considered to be an outcome of ongoing inflammatory processes (Libby, 2002a,b; Libby et al., 2002). TNF- $\alpha$, and IL-1 $\beta$ have been of much attention because of their role in orchestrating the inflammatory responses. TNF- $\alpha$ is a pleiotropic cytokine with pivotal role in acute phase reaction and inflammatory cascade (Bruunsgaard et al., 2000). TNF- $\alpha$ causes endothelial dysfunction and vascular remodelling (Galis et al., 1994; Hotamisligil et al., 1996; Nawroth and Stern, 1986). The proinflammatory effects of TNF are mediated through NF-kB-regulated proteins, such as cytokines, chemokines, cyclooxygenase-2 (COX-2), and 5- lipoxygenase (5-LOX), adhesion molecules etc. The IL-1 $\beta$ and IL-18 belong to the same structural family (IL-1 family, or IL-F) (Mauviel, 1993). They have a similar 3D structure, and their respective precursors are activated on cleavage by the intracellular cysteine protease (Dinarello, 2011; Nakanishi et al., 2001). IL-1 $\beta$ stimulates proliferation of endothelial cells and vascular smooth muscle cells (Kim et al., 2010; Yang et al., 2012). It increases the expression of cell adhesion molecule on the endothelial cell surface (Yang et al., 2012), modifies the endothelium to promote coagulation and thrombosis (Dinarello, 1991). Interleukin-18 is a pleiotropic proinflammatory cytokine known to be involved in atherosclerotic plaque progression and rupture (Mallat et al., 2001). IL-18 in combination with IL-2 stimulates a Th2 response and a Th1 response when acts synergistically with IL-12 to produce IFN-g (Nakanishi et al., 2001) which has a proatherogenic effect.

The minor allele frequencies of the TNF- $\alpha$, IL-18 and IL-1 $\beta$ SNPs as reported from earlier studies are $0.1 \%$ (Banday et al., 2016), 0.11\%, 0.14\% (Gupta et al., 2015) for TNF- $\alpha-308 \mathrm{G} / \mathrm{A}$, $-1031 \mathrm{~T} / \mathrm{C}$ and $-863 \mathrm{C} / \mathrm{A}$ respectively; 0.19\% (Birbian et al., 2013) for IL-18-137G/C; $0.25 \%$ (Daing et al., 2015), $0.54 \%$ and $0.57 \%$ (Bhat et al., 2014) for IL1 $\beta+3954 C / T,-511 C / T$, and $-31 C / T$ respectively. Single SNP evaluation gives only a feeble idea of the risk associated with the genes while haplotypes gives a broader coverage of the gene and its impact on disease risk. Therefore in this study, we investigated the polymorphisms and carried haplotyping of TNF- $\alpha$ at positions -308G/A (rs1800629), -1031T/ C (rs1799964), -863C/A (rs1800630); IL-18-137G/C (rs187238); IL-1 $\beta$ at positions $+3954 C / T$ ( $r$ 1143634), $-31 \mathrm{C} / \mathrm{T}$ (rs1143627) and $-511 \mathrm{C} / \mathrm{T}$ (rs16944) in coronary artery disease patients of Kashmir.

\section{Materials and methods}

\section{Collection of blood samples}

We carried out a case-control study to investigate the association between TNF- $\alpha$, IL-1 $\beta$ and IL-18 polymorphisms and CAD in Kashmiri population. We recruited 200 unrelated cases with documented coronary artery disease. Age and sex-matched healthy controls (260) without any apparent diseases were selected randomly to compare with the patient data. All studies were carried out according to the declaration of Helsinki guidelines. The study protocol was approved by the institutional ethics committee, SKIMS, Soura. The characteristics of the study population are given in Table 1. Peripheral blood samples were collected in EDTA vial under sterile conditions.

\section{Extraction of DNA}

Genomic DNA was extracted from the blood samples by using the modified phenol-chloroform method of DNA extraction (Sambrook and Russell, 2001). Quality of extracted DNA was checked on $0.8 \%$ Agarose gel.
Table 1

Characteristics of the study population.

\begin{tabular}{lll}
\hline Parameters & Cases (200) & Controls (260) \\
\hline Age & & $69 \%$ \\
$>50(\%)$ & $66 \%$ & $31 \%$ \\
$\leq 50(\%)$ & $34 \%$ & \\
Gender & & $68 \%$ \\
Male (\%) & $78 \%$ & $32 \%$ \\
Female (\%) & $22 \%$ & \\
& & - \\
Smoking status & & \\
Smoker (\%) & $59 \%$ & - \\
Non-smoker (\%) & $41 \%$ & \\
Family history & & \\
Yes (\%) & & \\
No (\%) & $83 \%$ & - \\
ECG report & $17 \%$ & \\
NSTEMI (\%) & & \\
STEMI ${ }^{2}(\%)$ & $30 \%$ & \\
Diabetes & $70 \%$ & \\
Diabetic (\%) & & \\
Non diabetic (\%) & & \\
Troponin T & $20 \%$ & \\
Positive (\%) & $80 \%$ & \\
Negative (\%) & & \\
\hline
\end{tabular}

Note: NSTEMI ${ }^{1}$ : Non ST-elevated myocardial infarction; STEMI $^{2}$ : ST-elevated myocardial infarction.

\section{Polymerase chain reaction}

The genomic DNA isolated served as template and the region encompassing variants were amplified by specific reverse and forward primers given in Table 2 . The genotyping of TNF- $\alpha$ and IL$1 \beta$ was done by RFLP-PCR while that of IL- 18 by Allele-specific primer PCR (AS-PCR). The Primers were designed by using Primer3, version 0.4.0 software. The reaction was carried out in a final volume of $25 \mu \mathrm{l}$ reaction containing about $50 \mathrm{ng}$ of genomic DNA, 0.5 ul of $10 \mathrm{mM}$ deoxynucleotide triphosphate (dNTP) (Thermo Fischer Scientific Inc. EU, Lithuania), $0.1-1.0 \mathrm{mM}$ of forward and reverse primers (Integrated DNA Technologies, Coralville, Lowa), 1.5 ul of $25 \mathrm{mM} \mathrm{Mgcl}_{2}, 2.5 \mathrm{ul}$ of $10 \mathrm{X}$ Taq Buffer and $1 \mathrm{U}$ of Taq Polymerase (Thermo Fischer Scientific Inc. EU, Lithuania). The PCR conditions were as follows: initial denaturing at $97^{\circ} \mathrm{C}$ for $4 \mathrm{~min}$, then 35 cycles of denaturation at $94^{\circ} \mathrm{C}$ for $30 \mathrm{~s}$, primer-dependent annealing (Table 2), and extension for $1 \mathrm{~min}$ at $72{ }^{\circ} \mathrm{C}$ followed by a final extension step at $72{ }^{\circ} \mathrm{C}$ for $7 \mathrm{~min}$. The reaction was performed in Applied biosystem 2320 thermal cycler. The amplicons were run on $2 \%$ ethidium-bromide stained agarose gel and checked under UV light. The size of amplicons corresponding to each of the SNP is given in Table 2 .

\section{Allele-specific PCR (AS-PCR)}

In case of IL-18-137G/C, two complementary reactions were established for each allele along with the common reverse primer and two allele-specific primers, according to the original protocol used by Giedraitis et al. (2001). A control forward primer was used to amplify a 446-bp fragment covering the polymorphic site to serve as an internal positive amplification control.

\section{Restriction fragment length polymorphism (RFLP)}

The amplicons of TNF- $\alpha$ and IL-1 $\beta$ SNPs were subjected to restriction digestion by using SNP specific restriction enzymes. The list of restriction enzymes specific to SNPs is given in Table 2. All 
Table 2

Primers, PCR conditions and genotyping.

\begin{tabular}{|c|c|c|c|c|}
\hline SNP & Primer sequence/Amplicon size (bp) & Annealing $\left({ }^{\circ} \mathrm{C}\right)$ & Restriction enzyme & Alleles corresponding to digestion products (bp) \\
\hline \multicolumn{5}{|c|}{ TNF- $\alpha-308 \mathrm{G} / \mathrm{A}$} \\
\hline $\mathrm{R}$ & $5^{\prime}-$ GGG ACA CAC AAG CAT CAA G-3' & & & G/G; 117 bp \\
\hline Amplicon & $117 \mathrm{bp}$ & & & $\mathrm{G} / \mathrm{A} ; 117,97,20 \mathrm{bp}$ \\
\hline \multicolumn{5}{|c|}{ TNF- $\alpha-1031 \mathrm{~T} / \mathrm{C}$} \\
\hline $\mathrm{F}$ & $5^{\prime}-$ TAT GTG ATG GAC TCA CCA GGT $-3^{\prime}$ & $63^{\circ} \mathrm{C}$ & Bbsl & $\mathrm{T} / \mathrm{T} ; 251 \mathrm{bp}$ \\
\hline $\mathrm{R}$ & $5^{\prime}$ CCT CTA CAT GGC CCT GTC TT $-3^{\prime}$ & & & $\mathrm{C} / \mathrm{C} ; 180$ and $71 \mathrm{bp}$ \\
\hline \multicolumn{5}{|c|}{ TNF- $\alpha-863 \mathrm{C} / \mathrm{A}$} \\
\hline $\mathrm{F}$ & $5^{\prime}$ - GGC TCT GAG GAA TGG GTT AC-3' & $59^{\circ} \mathrm{C}$ & Tai & $\mathrm{A} / \mathrm{A} ; 104,21 \mathrm{bp}$ \\
\hline $\mathrm{R}$ & $5^{\prime}$ - CTA CAT GGC CCT GTC TTC GTT ACG $-3^{\prime}$ & & & $\mathrm{C} / \mathrm{C} ; 125 \mathrm{bp}$ \\
\hline Amplicon & $125 \mathrm{bp}$ & & & $\mathrm{C} / \mathrm{A} ; 125,104$ and $21 \mathrm{bp}$ \\
\hline \multicolumn{5}{|c|}{ IL-18 -137G/C } \\
\hline & $5^{\prime}-$ CCA ATA GGA CTG ATT ATT CCG CA $3^{\prime}$ & & & \\
\hline $\mathrm{CF}$ & $5^{\prime}$ - AGG AGG GCA AAA TGC ACT GG $-3^{\prime}$ & $56^{\circ} \mathrm{C}$ & - & - \\
\hline \multicolumn{5}{|c|}{ IL-1 $\beta+3954 C / T$} \\
\hline $\mathrm{F}$ & 5'-GTTGTCATCAGACTTTGACC-3' & $59^{\circ} \mathrm{C}$ & TaqI & CC; $136,114 \mathrm{bp}$ \\
\hline $\mathrm{R}$ & 5'-TTCAGTTCATATGGACCAGA-3' & & & TT; 250 bp \\
\hline Amplicon & 250bp & & & TC; 250, 136 114bp \\
\hline \multicolumn{5}{|c|}{ IL-1 $\beta-31 C / T$} \\
\hline $\mathrm{F}$ & 5'-AGAAGCTTCCACCAATACTC-3' & $59^{\circ} \mathrm{C}$ & Alu $\mathrm{I}$ & TT; 137 and $102 \mathrm{bp}$ \\
\hline $\mathrm{R}$ & 5'-ACTAACTTTAGGGTGTCAG-5' & & & $\mathrm{C} / \mathrm{T} ; 239,137,102 \mathrm{bp}$ \\
\hline Amplicon & 239bp & & & C/C; 239 bp \\
\hline \multicolumn{5}{|c|}{ IL- $1 \beta-511 C / \mathrm{T}$} \\
\hline $\mathrm{F}$ & 5'-TGGCATTGATCTGGTTCATC- $3^{\prime}$ & $50^{\circ} \mathrm{C}$ & DdeI & $\mathrm{C} / \mathrm{C} ; 160,114,32 \mathrm{bp}$ \\
\hline $\mathrm{R}$ & 5'-GTTTAGGAATCTTCCCACTT-3' & & & $\mathrm{C} / \mathrm{T} ; 160,146,114,32 \mathrm{bp}$ \\
\hline Amplicon & 302bp & & & $\mathrm{T} / \mathrm{T} ; 60$ and 146bp \\
\hline
\end{tabular}

the restriction enzymes were supplied by Thermo Fischer Scientific Inc. EU, Lithuania. A $10 \mathrm{ul}$ of amplified products were digested with corresponding restriction enzymes in a total of $20 \mathrm{ul}$ reaction volume containing $1 \mathrm{X}$ buffer as supplied by the manufacturer. The reactions mixtures were incubated overnight at $37^{\circ} \mathrm{C}$ and the restriction fragments were resolved on $3 \%$ ethidium-bromide stained agarose gel and visualized under UV. The restriction fragments corresponding to different alleles are given in Table 2 .

\section{Statistical analysis}

The chi-square $\left(\chi^{2}\right)$ was used for assessment of categorical data and student's $t$-test for continuous variable analysis. Logistic regression analysis was performed to adjust age, gender, and other characteristics which significantly differed between the cases and controls in univariate analysis. Statistical analysis was carried out using the SPSS 20 software. Haplotype analysis and Linkage disequilibrium were performed by using the Iconcologia software (Catalan Institute of Oncology). The coefficient of linkage disequilibrium (D') $>0.8$ and a $P$-value of $<0.05$ was considered to be statistically significant.

\section{Results}

The allele frequencies and genotypic distribution in the control and patient groups are shown in Tables 3 and 4. The Odds Ratios (ORs) for each genotype was tested as a three-class variable such as codominant, dominant and recessive models. In case of the TNF- $\alpha$ $-308 \mathrm{G} / \mathrm{A}$ (rs1800629) polymorphism we found G/A-A/A genotype
Table 3

Allele frequency.

\begin{tabular}{|c|c|c|c|}
\hline SNP & All subjects (\%) & Cases (\%) & Controls (\%) \\
\hline \multicolumn{4}{|c|}{ TNF- $\alpha-308 \mathrm{G} / \mathrm{A}$} \\
\hline G & 0.77 & 0.69 & 0.84 \\
\hline A & 0.22 & 0.31 & 0.16 \\
\hline \multicolumn{4}{|c|}{ TNF- $\alpha-1031 \mathrm{~T} / \mathrm{C}$} \\
\hline $\mathrm{T}$ & 0.73 & 0.82 & 0.69 \\
\hline C & 0.27 & 0.18 & 0.31 \\
\hline \multicolumn{4}{|c|}{ TNF- $\alpha-863 \mathrm{C} / \mathrm{A}$} \\
\hline $\mathrm{C}$ & 0.82 & 0.74 & 0.93 \\
\hline A & 0.18 & 0.26 & 0.07 \\
\hline \multicolumn{4}{|c|}{ IL-18 -137G/C } \\
\hline G & 0.55 & 0.55 & 0.56 \\
\hline C & 0.45 & 0.45 & 0.44 \\
\hline \multicolumn{4}{|c|}{$\mathrm{lL}-1 \beta+3954 \mathrm{C} / \mathrm{T}$} \\
\hline C & 0.73 & 0.77 & 0.71 \\
\hline $\mathrm{T}$ & 0.27 & 0.23 & 0.29 \\
\hline \multicolumn{4}{|c|}{ IL-1 $\beta-31 C / T$} \\
\hline C & 0.67 & 0.68 & 0.67 \\
\hline $\mathrm{T}$ & 0.33 & 0.32 & 0.33 \\
\hline \multicolumn{4}{|c|}{ IL-1 $\beta-511 C / T$} \\
\hline C & 0.7 & 0.62 & 0.72 \\
\hline $\mathrm{T}$ & 0.3 & 0.38 & 0.28 \\
\hline
\end{tabular}

to be associated with an increased risk of CAD in dominant model ( $\mathrm{OR}=0.43 ; 95 \% \mathrm{CI}=0.23-0.82 ; P=0.0099$ ). Its role in disease association is also clear from its allele frequency $(0.31 \%$ in cases and $0.16 \%$ in controls). For $-1031 \mathrm{~T} / \mathrm{C}$ (rs1799964) the frequency of heterozygous $\mathrm{T} / \mathrm{C}$ was $18.3 \%$ in cases and $44.4 \%$ in controls. It was found to have a protective or an inverse association with the 
Table 4

Association of SNPs with response status (adjusted for age and gender).

\begin{tabular}{|c|c|c|c|c|c|c|}
\hline SNP & Model & Genotype & Cases & Controls & $\begin{array}{l}\text { OR } \\
(95 \% \mathrm{CI}) \\
\end{array}$ & $P$-value* \\
\hline TNF- $\alpha-308 G / A$ & Dominant & $\begin{array}{l}\mathrm{G} / \mathrm{G} \\
\mathrm{G} / \mathrm{A}-\mathrm{A} / \mathrm{A}\end{array}$ & $\begin{array}{l}54.3 \% \\
45.7 \%\end{array}$ & $\begin{array}{l}72.1 \% \\
27.9 \%\end{array}$ & $\begin{array}{l}1.00 \\
0.43(0.23-0.82)\end{array}$ & 0.0099 \\
\hline TNF- $\alpha-1031 \mathrm{~T} / \mathrm{C}$ & Over dominant & $\begin{array}{l}\mathrm{T} / \mathrm{T}-\mathrm{C} / \mathrm{C} \\
\mathrm{T} / \mathrm{C}\end{array}$ & $\begin{array}{l}81.7 \% \\
18.3 \%\end{array}$ & $\begin{array}{l}55.6 \% \\
44.4 \%\end{array}$ & $\begin{array}{l}1.00 \\
4.08(1.99-8.37)\end{array}$ & $<0.0001$ \\
\hline TNF- $\alpha-863 C / A$ & Recessive & $\begin{array}{l}\mathrm{C} / \mathrm{C}-\mathrm{A} / \mathrm{C} \\
\mathrm{A} / \mathrm{A}\end{array}$ & $\begin{array}{l}79.7 \% \\
20.3 \%\end{array}$ & $\begin{array}{l}95.8 \% \\
4.2 \%\end{array}$ & $\begin{array}{l}1.00 \\
0.10(0.03-0.38)\end{array}$ & $1 e-04$ \\
\hline IL-18 -137G/C & Over dominant & $\begin{array}{l}\mathrm{G} / \mathrm{G}-\mathrm{C} / \mathrm{C} \\
\mathrm{G} / \mathrm{C}\end{array}$ & $\begin{array}{l}27.5 \% \\
72.5 \%\end{array}$ & $\begin{array}{l}17.4 \% \\
82.6 \%\end{array}$ & $\begin{array}{l}1.00 \\
1.78(0.74-4.29)\end{array}$ & 0.2 \\
\hline IL-1 $\beta+3954 C / T$ & Over dominant & $\begin{array}{l}\mathrm{C} / \mathrm{C}-\mathrm{T} / \mathrm{T} \\
\mathrm{C} / \mathrm{T}\end{array}$ & $\begin{array}{l}73.3 \% \\
26.7 \%\end{array}$ & $\begin{array}{l}56.4 \% \\
43.6 \%\end{array}$ & $\begin{array}{l}1.00 \\
1.68(0.83-3.41)\end{array}$ & 0.15 \\
\hline IL- $1 \beta-31 \mathrm{C} / \mathrm{T}$ & Over dominant & $\begin{array}{l}\mathrm{C} / \mathrm{C}-\mathrm{T} / \mathrm{T} \\
\mathrm{C} / \mathrm{T}\end{array}$ & $\begin{array}{l}56.2 \% \\
43.8 \%\end{array}$ & $\begin{array}{l}61.1 \% \\
38.9 \%\end{array}$ & $\begin{array}{l}1.00 \\
0.83(0.43-1.59)\end{array}$ & 0.58 \\
\hline IL-1 $\beta-511 C / T$ & Recessive & $\begin{array}{l}\mathrm{C} / \mathrm{C}-\mathrm{C} / \mathrm{T} \\
\mathrm{T} / \mathrm{T}\end{array}$ & $\begin{array}{l}75.3 \% \\
24.7 \%\end{array}$ & $\begin{array}{l}90.1 \% \\
9.9 \%\end{array}$ & $\begin{array}{l}1.00 \\
0.32(0.13-0.81)\end{array}$ & 0.018 \\
\hline
\end{tabular}

Note: Chi square test $\left(\chi^{2}\right)$ test used for genotypic analysis and $P$ value of $<0.05$ at $95 \%$ confidence interval considered to be statistically significant.

disease in an overdominant model $(\mathrm{OR}=4.08 ; 95 \% \mathrm{CI}=1.99-8.37$; $P<0.0001)$. The allele frequency of variant $C$ was seen to be higher in controls $(0.31 \%)$, than in cases $(0.18 \%)$. For TNF- $\alpha-863 \mathrm{C} / \mathrm{A}$ (rs1800630) the frequency of variant genotype A/A was $20.3 \%$ in cases and $4.2 \%$ in controls. It was found to have a significant association with the development of disease in recessive model $(\mathrm{OR}=0.10 ; 95 \% \mathrm{CI}=0.03-0.38 ; P=0.0001)$. The allele frequency of A was 0.26 in cases and 0.07 in controls. In case of IL-18-137G/C (rs187238) the frequency of variant genotype in cases and controls was $72.5 \%$ and $82.6 \%$ respectively. There was no significant association in an overdominant model $(\mathrm{OR}=1.78,95 \% \mathrm{CI}=0.74-$ 4.29 and $P=0.2$. For IL-1 $\beta+3954 \mathrm{C} / \mathrm{T}$ (rs1143634) the frequency of variant genotype $\mathrm{C} / \mathrm{T}$ was found to be $26.7 \%$ and $43.6 \%$ in cases and controls respectively. The allele frequencies were $0.23 \%$ and $0.29 \%$ in cases and controls respectively. No significant difference was seen in an overdominant model $(\mathrm{OR}=1.68 ; 95 \% \mathrm{CI}=0.83-3.41$; $P=0.15$ ). For IL-1 $\beta-31 \mathrm{C} / \mathrm{T}$ (rs1143627,) the frequency of variant genotype $\mathrm{C} / \mathrm{T}$ in cases and controls was $43.8 \%$ and $38.9 \%$ respectively. There was no significant association in an overdominant model $(\mathrm{OR}=0.83 ; 95 \% \mathrm{CI}=0.43-1.59 ; P=0.58)$. Also, no significant difference between allele frequencies in cases $(0.32 \%)$ and controls (0.33\%) was found. In case of IL-1 $\beta-511 C / T$ (rs16944), the frequency of homozygous variant $\mathrm{T} / \mathrm{T}$ was found to be $24.7 \%$ and $9.9 \%$ in cases and controls respectively. A significant association was seen in recessive model $(\mathrm{OR}=0.32 ; 95 \% \mathrm{CI}=0.13$ $-0.81 ; P=0.018)$. A significant difference was seen in allele frequencies within cases $(0.38 \%)$ and controls $(0.28 \%)$.

Haplotype analysis revealed the haplotype GTCGTTT of TNF- $\alpha$ at positions -308 (rs1800629), -1031 (ra1799964), 863 (rs1800630), IL-18-137 (rs187238) and of IL-1 $\beta$ at positions +3954 (rs1143634), -31 (1143627) and -511 (16944) to be highly associated with CAD risk with a $P$ value of 6e-04 followed by ATCGCC and GTACCTC with
$P$ values of 0.019 and 0.028 respectively as shown in Table 5. None of the polymorphic sites of the genes was in linkage disequilibrium with each other as shown by D' statistics in Table 6 .

Coronary artery disease clinicopathological factors and TNF- $\alpha$, IL-18 and IL-1 $\beta$ genotypes by logistic regression analysis

The TNF- $\alpha-308 \mathrm{G} / \mathrm{A}$ was seen to be associated with diabetic status. The G/A - A/A genotype of TNF- $\alpha-308 \mathrm{G} / \mathrm{A}$ polymorphic site was seen to be higher in non-diabetics with an OR of 3.52; $95 \%$ CI 1.54-8.07 and $P$ value 0.0019. From the recessive model the $\mathrm{C} / \mathrm{C}$ genotype of TNF- $\alpha-1031 \mathrm{~T} / \mathrm{C}$ was observed to be highly associated with the NSTEMI (non ST-elevated Myocardial infarction) with an OR $0.11 ; 95 \% \mathrm{CI} 0.03-0.41$ and $P$ value $4 \mathrm{e}-04$. Also, from the recessive model the $C / C$ genotype of TNF- $\alpha-1031 \mathrm{~T} / \mathrm{C}$ was seen to be higher in the individuals having no family history of coronary artery disease, OR 4.46; 95\% CI 1.35-14.81 and $P$ value 0.018. From the recessive model, the $C / C$ genotype of IL-18-137G/C was found to be higher in the individuals having no history of coronary artery disease with a $P$ value of 0.005 . From the overdominant model the $C / T$ genotype of IL-1 $\beta+3954$ was seen to be higher in individuals with family history of CAD, OR $0.32 ; 95 \%$ CI $0.10-0.99$ and $P$ value 0.029 . From the overdominant model the T/T genotype of IL-1 $\beta$ -511 was seen to be higher in individuals with family history of CAD, OR $0.31 ; 95 \%$ CI $0.10-0.95$ and $P$ value 0.024 .

\section{Discussion}

Traditional risk factors have played an attributable role in the development of coronary artery disease however these conventional factors can only contribute $50 \%$ to the total risk for the development of CAD (Edmondson et al., 2013; Gibson et al., 1997;

Table 5

Haplotype association with response status (adjusted by Age + Gender).

\begin{tabular}{|c|c|c|c|c|c|c|c|c|c|}
\hline TNF $\alpha-308 \mathrm{G} / \mathrm{A}$ & TNF $\alpha-1031 \mathrm{~T} / \mathrm{C}$ & $\mathrm{TNF} \alpha-863 \mathrm{C} / \mathrm{A}$ & IL-18 $-137 \mathrm{G} / \mathrm{C}$ & IL-1 $\beta+3954 C / T$ & $\mathrm{IL}-1 \beta-31 \mathrm{C} / \mathrm{T}$ & $\mathrm{IL}-1 \beta-511 \mathrm{C} / \mathrm{T}$ & Freq. & OR $(95 \% \mathrm{CI})$ & $P$-value* \\
\hline G & $\mathrm{T}$ & $\mathrm{C}$ & $\mathrm{C}$ & $\mathrm{C}$ & C & $\mathrm{C}$ & 0.132 & 1.00 & - \\
\hline A & $\mathrm{T}$ & $\mathrm{C}$ & G & $\mathrm{C}$ & C & C & 0.0371 & $0.03(0.00-0.55)$ & 0.019 \\
\hline G & $\mathrm{T}$ & $\mathrm{C}$ & G & $\mathrm{T}$ & $\mathrm{T}$ & $\mathrm{T}$ & 0.0233 & $0.00(0.00-0.03)$ & $6 e-04$ \\
\hline G & $\mathrm{T}$ & A & $\mathrm{C}$ & $\mathrm{C}$ & $\mathrm{T}$ & $\mathrm{C}$ & 0.0197 & $0.01(0.00-0.56)$ & 0.028 \\
\hline
\end{tabular}

Note: OR - odds ratio; $\mathrm{CI}$ - Confidence interval. ${ }^{*} P<0.05,{ }^{*} P$-value was computed by adjusting age and gender as covariates. 
Table 6

Linkage disequilibrium by coefficient of Linkage disequilibrium (D').

\begin{tabular}{|c|c|c|c|c|c|c|c|}
\hline & TNF- $\alpha-308 \mathrm{G} / \mathrm{A}$ & TNF- $\alpha-1031 \mathrm{~T} / \mathrm{C}$ & TNF- $\alpha-863 \mathrm{C} / \mathrm{A}$ & IL-18 -137G/C & $1 \mathrm{~L}-1 \beta+3954 \mathrm{C} / \mathrm{T}$ & IL-1 $\beta-31 \mathrm{C} / \mathrm{T}$ & IL-1 $\beta-511 C / T$ \\
\hline TNF- $\alpha-308 \mathrm{G} / \mathrm{A}$ & - & 0.0259 & 0.024 & 0.1467 & 0.0329 & 0.1151 & 0.077 \\
\hline TNF- $\alpha-1031 \mathrm{~T} / \mathrm{C}$ & - & - & 0.0218 & 0.0926 & 0.0098 & 0.1909 & 0.2276 \\
\hline TNF- $\alpha-863 C / A$ & - & - & - & 0.0828 & 0.0051 & 0.0234 & 0.4424 \\
\hline IL-18 $-137 \mathrm{G} / \mathrm{C}$ & - & - & - & - & 0.0994 & 0.3009 & 0.0404 \\
\hline $\mathrm{IL}-1 \beta+3954 \mathrm{C} / \mathrm{T}$ & - & - & - & - & - & 0.4444 & 0.2437 \\
\hline IL-1 $\beta-31 \mathrm{C} / \mathrm{T}$ & - & - & - & - & - & - & 0.4469 \\
\hline $\mathrm{IL}-1 \beta-511 \mathrm{C} / \mathrm{T}$ & - & - & - & - & - & - & - \\
\hline
\end{tabular}

Note: D' value $>0.8$, statistically significant.

Muhlestein, 2002; Nilsson et al., 2006; Ohira and Iso, 2013; Simon and Vijayakumar, 2013; Yusuf et al., 2004).

Genetic factors might contribute to the other half of the total risk factors, and many polymorphisms are considered to be associated with the onset and development of CAD (Lieb and Vasan, 2013; Lin et al., 2014; Simon and Vijayakumar, 2013; Wang et al., 2013; Wu et al., 2014; Xu et al., 2014). The new insights in understanding the role of inflammation in the pathogenesis of disease not only improve our understanding of the disease but also have clinical significance in risk stratification and designing of therapy for this menace of growing importance. The role of TNF- $\alpha$ $-308 \mathrm{G} / \mathrm{A}$ in the development of CAD is both contradictory and inconclusive. A meta-analysis and case-control conducted by Chu et al. (2012) in Asian and Caucasian showed no relation between TNF- $\alpha$ polymorphism and CHD/MI risk.

Our study showed a significant association of TNF- $\alpha-308 \mathrm{G} / \mathrm{A}$ with the susceptibility to CAD. Our study is in accordance with that of Elahi et al. (2008) who showed 308A genotype to be related to more severe form of coronary atherosclerosis in British CAD patients. Also, in the Italian population a case-control study conducted by Szalai et al. (2002) identified TNF- $\alpha-308 \mathrm{G} / \mathrm{A}$ associated with $\mathrm{CHD} / \mathrm{MI}$ risk.

The TNF- $\alpha-308$ A allele has been found to be associated with higher inducible and constitutive TNF- $\alpha$ expression than TNF- $\alpha$ -308G allele (Abraham and Kroeger, 1999; Wilson et al., 1997). The reporter gene assay conducted by Wilson et al. (1997) showed the presence of TNF- $\alpha-308 \mathrm{~A}$ allele within the extended MHC haplotype HLA-A1-B8-DR3-DQ2 which is responsible for high TNF- $\alpha$ production.

It has further been shown that this allele alters a transcription factor binding site by the formation of an altered composite transcriptional element. Thus, the binding of transcriptional factors to the -323 to -285 composite element is affected which is associated with the higher transcriptional activity of TNF- $\alpha$ gene (Abraham and Kroeger, 1999).

Moreover, TNF- $\alpha-308 \mathrm{G} / \mathrm{A}$ showed a significant association with the development of CAD with much preponderance in nondiabetics.

For TNF- $\alpha-1031 \mathrm{~T} / \mathrm{C}$ our research findings showed an inverse role of $\mathrm{T} / \mathrm{C}$ under an overdominant model. The TNF- $\alpha-1031 \mathrm{C}$ frequency was higher in controls $(0.31 \%)$ than in cases $(0.18 \%)$. Our results are in accordance to that of Oda et al. (2007) who reported TNF- $\alpha-1031 \mathrm{C}$ allele acts as a protective factor in atherosclerotic severity. The TNF- $\alpha-1031 \mathrm{~T} / \mathrm{C}$ showed an inverse or a protective role in the CAD development and was common in patients with NSTEMI (non ST-elevated myocardial infarction) and with those having family history of CAD.

We observed a significant difference in the TNF- $\alpha$ gene $-863 \mathrm{C}$ / A polymorphism between the patients and control group $(P<0.0001)$. The $-863 \mathrm{~A}$ allele was more common in patients $(0.26 \%)$ as compared to $(0.07 \%)$ healthy controls. Higher frequency of the variant allele TNF- $\alpha-863 \mathrm{~A}$ indicates a significant association of this polymorphism with CHD in the population studied. Our study is in agreement with that of Xiang et al. (2004) who also revealed a significant difference in the frequency of $-863 \mathrm{~A}$ allele between patients and controls. Some studies however reported a nonsignificant difference in the $-863 \mathrm{C} / \mathrm{A}$ genotype frequency between patients with $\mathrm{CHD}$, myocardial infarction, and cardiomyopathy (Bennet et al., 2006; Koch et al., 2003; Liang et al., 2010). Also, TNF- $\alpha-863$ C/A was found to be strongly influencing the development of disease especially in individuals with no family history.

In case of IL-18-137G/C, no significant association was found between polymorphism and the overall risk of disease. The IL-18137C allele frequency between cases $(0.45 \%)$ and $(0.44 \%)$ was nonsignificant. It does not contribute to the risk of CAD development as inferred from the co-dominant, dominant, overdominant and recessive models. Our study is in agreement with that of Thompson et al. (2007) and Hernesniemi et al. (2010a,b). The SNP was more common in individuals with no family history of the disease.

IL-1 $\beta+3954$ C/T polymorphism did not show any significant association with the disease. There was no significant difference in allele frequency between cases and controls $0.23 \%$ and $0.29 \%$ respectively. The meta-analysis conducted by Zhou et al. (2012) have also shown no association between IL-1 $\beta+3954 C / T$ polymorphic site and Coronary Heart Disease Risk. In IL-1 $\beta$ $-31 \mathrm{C} / \mathrm{T}$ none of the genetic models confirmed its role in disease development. Also, the allele frequency of $\mathrm{T}$ in cases $(0.32 \%)$ and controls $(0.33 \%)$ was nonsignificant. Although various studies have highlighted the role of IL-1 $\beta-31 \mathrm{C} / \mathrm{T}$ in the inflammatory responses and disease risk (Lind et al., 2005; Chen et al., 2006; Haukim et al., 2002 ) our study could not confirm the association. Both of the SNPs showed association with the development of disease in individuals with the family history of the CAD.

IL-1 $\beta-511 \mathrm{~T} / C$ polymorphism showed a significant association with the coronary artery disease. The frequency of $\mathrm{T}$ allele was found to be $0.38 \%$ in cases and $0.28 \%$ in controls. Our study is in agreement with that of Dziedzic et al. (2005) conducted in Poland population. Moreover, the association of the IL-1 $\beta-511 \mathrm{C} / \mathrm{T}$ and risk of MI and ischemic stroke at a young age has been found in Italian population (Iacoviello et al., 2005). The association of this SNP with coronary artery disease risk has been reported in African-Brazilians as well (Rios et al., 2010). The SNP was also found associated with the development of disease in individuals with family history.

\section{Conclusions}

Conclusively, the present findings emphasize the role of TNF- $\alpha$ $-308 \mathrm{~A}$ and $-863 \mathrm{~A}$ allele in the pathogenesis of coronary artery disease. The TNF- $\alpha-1031 \mathrm{C}$ allele showed an inverse relation with the disease and it seems to have a protective role against the development of disease in the Kashmiri population. IL-18-137C allele didn't show any association with the disease. IL-1 $\beta+3954 \mathrm{~T}$ and IL-1 $\beta-31$ T allele showed no contribution to the disease while IL-1 $\beta-511$ T allele showed significant association with the disease and are especially threatening in the individuals who are having 
the family history of coronary artery disease. The haplotype GTCGTTT was found more common in the CAD individuals. These polymorphisms in synchrony with specific risk factors could serve as potential biomarkers for risk stratification and disease evaluation. The gene-environment interaction in specific populations could help in identifying the vulnerable populations. The observations need to be evaluated in a larger cohort for the better understanding of their role in the development of coronary artery disease at ethnicity level and for possible therapeutic strategies and prevention of its secondary evolution.

\section{Conflict of interests}

The authors have no conflicts of interests to declare.

\section{Acknowledgements}

The study was supported by a grant from the University grants commission (UGC) India.

\section{References}

Abraham, L.J., Kroeger, K.M., 1999. Impact of the -308 TNF promoter polymorphism on the transcriptional regulation of the TNF gene: relevance to disease. J Leukoc. Biol. 66 (4), 562-566.

Antoniades, C., Tousoulis, D., Tountas, C., Tentolouris, C., Toutouza, M., Vasiliadou, C. et al., 2004. Vascular endothelium and inflammatory process, in patients with combined type 2 diabetes mellitus and coronary atherosclerosis: the effects of vitamin C. Diabet. Med. 21, 552-558.

Banday, M.Z., Balkhi, H.M., Hamid, Z., Sameer, A.S., Chowdri, N.A., Haq, E., 2016. Tumour necrosis factor- $\alpha$ (TNF- $\alpha$ )-308G/A promoter polymorphism in colorectal cancer in ethnic Kashmiri population -a case control study in a detailed perspective. Meta Gene 9, 128-136.

Bennet, A.M., van Maarle, M.C., Hallqvist, J., Morgenstern, R., Frostegard, J., Wimna, B., et al., 2006. Association of TNF- $\alpha$ serum levels and TNFA promoter polymorphisms with risk of myocardial infarction. Atherosclerosis 187 (2), 408-414.

Bhat, I.A., Naykoo, N.A., Qasim, I., Ganie, F.A., Yousuf, Q., Bhat, B.A., et al., 2014 Association of interleukin 1 beta (IL-1B) polymorphism with mRNA expression and risk of non-small cell lung cancer. Meta Gene 2, 123-133.

Birbian, N., Singh, J., Jindal, S.K., 2013. Protective role of IL-18-137G/C polymorphism in a North Indian population with asthma: a pilot study. Cytokine 61 (1), 188193.

Bruunsgaard, H., Skinhoj, P., Pedersen, A.N., Schroll, M., Pedersen, B.K., 2000. Ageing, tumour necrosis factor alpha (TNF-alpha) and atherosclerosis. Clin. Exp. Immunol. 121, 255-260.

Chen, H., Wilkins, L.M., Aziz, N., Cannings, C., Wyllie, D.H., Bingle, C., et al., 2006 Single nucleotide polymorphisms in the human interleukin-1 B gene affect transcription according to haplotype context Hum. Mol. Genet. 15 (4), 519-529.

Chu, H., Yang, J., Mi, S., Bhuyan, S.S., Li, J., Zhong, L., et al., 2012. Tumour necrosis factor-alpha G-308 A polymorphism and risk of coronary heart disease and myocardial infarction: a case-control study and meta-analysis. J. Cardiovasc. Dis. Res. 3 (2), 84-90.

Daing, A., Singh, S.V., Saimbi, C.H., Khan, M.A., Rath, S.K., 2015. Single nucleotide polymorphisms at interleukin (IL) $-1 \beta+3954$ and vitamin D receptor (VDR) Taql in chronic periodontitis patients: a pilot study in North Indian population. J. Int. Clin. Dent. Res. Organ. 7 (1), 18-23.

Dharmender, N.K., Sharma, N.R., Ali, G., Margoob, M.A., Mushtaq, H., Kumar, P., Nehra, S., 2012. Comparative study of prevalence of psychological distress factors in coronary heart disease patients living under disturbed conditions and a normal place of North India. Delhi Psychiatry J. 15 (1), 99-106.

Dinarello, C.A., 1991. Interleukin 1 and interleukin 1 receptor antagonism. Blood 77, 1627-1652.

Dinarello, C.A., 2011. Interleukin-1 in the pathogenesis and treatment of inflammatory diseases. Blood 117, 3720-3732.

Dziedzic, T., Slowik, A., Pera, J., Szczudlik, A., 2005. Interleukin 1 Beta polymorphism $(-511)$ and risk of stroke due to small vessel disease. Cerebrovasc. Dis. 20, 299303.

Edmondson, D., Newman, J.D., Whang, W., Davidson, K.W., 2013. Emotional triggers in myocardial infarction: do they matter? Eur. Heart J. 34 (4), 300-306.

Elahi, M.M., Gilmour, A., Matata, B.M., Mastana, S.S., 2008. A variant of position -308 of the tumour necrosis factor alpha gene promoter and the risk of coronary heart disease. Heart Lung Circ. 17, 14-18.

Galis, Z.S., Muszynski, M., Sukhova, G.K., Simon Morrissey, E., Unemori, E.N., Lark, M. W., et al., 1994. Cytokine-stimulated human vascular smooth muscle cells synthesize a complement of enzymes required for extracellular matrix digestion. Circ. Res. 75, 181-189.

Gibson, C.M., Cannon, C.P., Greene, R.M., Sequeira, R.F., Margorien, R.D., Leya, F., et al. 1997. Rescue angioplasty in the thrombolysis in myocardial infarction (TIMI) 4 trial. Am. J. Cardiol. 80 (1), 21-26.
Giedraitis, V., He, B., Huang, W.X., Hillert, J., 2001. Cloning and mutation analysis of the human IL-18 promoter: a possible role of polymorphisms in expression regulation. J. Neuroimmunol. 112 (1-2), 146-152.

Gupta, S., Mehndiratta, M., Kalra, S., Kalra, O.M., Shukla, R., Gambhir, J.K., 2015. Association of Tumour Necrosis Factor (TNF) promoter polymorphisms with plasma TNF- $\alpha$ levels and susceptibility to diabetic nephropathy in North Indian population. J. Diabetes Complicat. 29 (3), 338-342.

Haukim, N., Bidwel, J.L., Smith, A.J., Keen, L.J., Gallagher, G., Kimberly, R., et al., 2002. Cytokine gene polymorphism in human disease: on-line databases, supplement 2. Genes Immunol. 3 (6), 313-330.

Hernesniemi, J.A., Anttila, K., Nieminen, T., Kähönen, M., Mononen, N., Nikus, K., et al., 2010a. IL-18 gene polymorphism, cardiovascular mortality and coronary artery disease. Eur. J. Clin. Invest. 40 (11), 994-1001.

Hernesniemi, J.A., Heikkilä, A., Raitakari, O.T., Kähönen, M., Juonala, M., HutriKähönen, N., et al., 2010b. Interleukin-18 gene polymorphism and markers of subclinical atherosclerosis. The Cardiovascular Risk in Young Finns Study. Ann. Med. 42 (3), 223-230.

Hotamisligil, G.S., Peraldi, P., Budavari, A., Ellis, R., White, M.F., Spiegelman, B.M., 1996. IRS- 1-mediated inhibition of insulin receptor tyrosin kinase activity in TNF-a and obesity induced insulin resistance. Science 271 (5249), 665-668.

Iacoviello, L., Di Castelnuovo, A., Gattone, M., Pezzini, A., Assanelli, D., Lorenzet, R., et al., 2005. Polymorphisms of the interleukin-1beta gene affect the risk of myocardial infarction and ischemic stroke at young age and the response of mononuclear cells to stimulation in vitro. Arterioscler. Thromb. Vasc. Biol. 25, 222-227.

Joshi, P., Islam, S., Pais, P., Reddy, S., Dorairaj, P., Kazmi, K., et al., 2007. Risk factors for early myocardial infarction in South Asians compared with individuals in other countries. JAMA 297 (3), 286-294.

Kamili, M.A., Dar, I.H., Ali, G., Wazir, H.S., Hussain, S., 2007. Prevalence of coronary heart disease in Kashmir. Indian Heart J. 59 (1), 44-49.

Kim, H.J., Kim, M.Y., Hwang, J.S., Kim, H.J., Lee, J.H., Chang, K.C., et al., 2010. PPAR delta inhibits IL-1beta-stimulated proliferation and migration of vascular smooth muscle cells via up-regulation of IL-1Ra. Cell. Mol. Life Sci. 67 (12), 2119-2130.

Koch, W., Tiroch, K., von Beckerath, N., Schömig, A., Kastrati, A., 2003. Tumour necrosis factor- $\alpha$, lymphotoxin- $\alpha$, and interleukin-10 gene polymorphisms and restenosis after coronary artery stenting. Cytokine 24 (4), 161-171.

Liang, W.B., Lv, M.L., Su, X.W., Gao, L.B., Luo, H.B., Zhang, L., 2010. Association of tumor necrosis factor gene polymorphisms with susceptibility to dilated cardiomyopathy in a Han Chinese population. DNA Cell Biol. 29 (10), 625-628.

Libby, P., Ridker, P.M., Maseri, A., 2002. Inflammation and atherosclerosis. Circulation 105, 1135-1143.

Libby, P., 2002a. Atherosclerosis: the new view. Sci. Am. 286, 46-55.

Libby, P., 2002b. Inflammation in atherosclerosis. Nature 420, 868-874.

Lieb, W., Vasan, R.S., 2013. Genetics of coronary artery disease. Circulation 128 (10), $1131-1138$

Lin, B., Huang, Y., Zhang, M., Wang, J., Wu, Y., 2014. Association between apolipoprotein C3 Sst I, T-455C, C-482T and C1100T polymorphisms and risk of coronary heart disease. BMJ Open 4 (1), e004156.

Lind, H., Zienolddiny, S., Ryberg, D., Skaug, V., Phillips, D.H., Haugen, A., 2005 Interleukin 1 receptor antagonist gene polymorphism and risk of lung cancer: a possible interaction with polymorphisms in the interleukin 1 beta gene. Lung Cancer 50 (3), 285-290.

Lozano, R., Naghavi, M., Foreman, K., Lim, S., Shibuya, K., Aboyans, V., et al., 2012. Global and regional mortality from 235 causes of death for 20 age groups in 1990 and 2010: a systematic analysis for the Global Burden of Disease Study. Lancet 380 (9859), 2095-2128.

Mallat, Z., Corbaz, A., Scoazec, A., Graber, P., Alouani, S., Esposito, B., et al., 2001. Interleukin-18/interleukin-18 binding protein signalling modulates atherosclerotic lesion development and stability. Circ. Res. 89 (7), E41-E45.

Mauviel, A., 1993. Cytokine regulation of metalloproteinase gene expression. J. Cell. Biochem. 53, 288-295.

Muhlestein, J.B., 2002. Secondary prevention of coronary artery disease with antimicrobials: current status and future directions. Am. J. Cardiovasc. Drugs 2 (2), 107-118.

Nakanishi, K., Yoshimoto, T., Tsutsui, H., Okamura, H., 2001. Interleukin-18 is a unique cytokine that stimulates both Th1 and Th2 responses depending on its cytokine milieu. Cytokine Growth Factor Rev. 12, 53-72.

Nawroth, P.P., Stern, D.M., 1986. Modulation of endothelial cell hemostatic properties by tumour necrosis factor. J. Exp. Med. 163, 740-745.

Nilsson, P.M., Nilsson, J.A., Berglund, G., 2006. Population-attributable risk of coronary heart disease risk factors during long-term follow-up: the Malmo preventive project. J. Intern. Med. 260 (2), 134-141.

Oda, K., Tanaka, N., Arai, T., Araki, J., Song, Y., Zhang, L., et al., 2007. Polymorphisms in pro and anti-inflammatory cytokine genes and susceptibility to atherosclerosis: a pathological study of 1503 consecutive autopsy cases. Hum. Mol. Genet. 16 (6) 592-599.

Ohira, T., Iso, H., 2013. Cardiovascular disease epidemiology in Asia: an overview. Circ. J. 77 (7), 1646-1652.

Rios, D.L., Cerqueira, C.C., Bonfim-Silva, R., Araújo, L.J., Pereira, J.F., Gadelha, S.R., Barbossa, A.A., 2010. Interleukin-1 beta and interleukin-6 gene polymorphism associations with angiographically assessed coronary artery disease in Brazilians. Cytokine 50 (3), 292-296.

Sambrook, J., Russell, D.W., 2001. Molecular Cloning: A Laboratory Manual. Cold Spring Harbor, New York. 
Simon, A.S., Vijayakumar, T., 2013. Molecular studies on coronary artery disease - a review. Indian J. Clin. Biochem. 28 (3), 215-226.

Szalai, C., Fust, G., Duba, J., Kramer, J., Romics, L., Prohaszka, Z., et al., 2002. Association of polymorphisms and allelic combinations in the tumour necrosis factoralpha - complement MHC region with coronary artery disease. J. Med. Genet. 39, 46-51.

Thompson, S.R., Sanders, J., Stephens, J.W., Miller, G.J., Humpries, S.E., 2007 A common interleukin 18 haplotype is associated with higher body mass index in subjects with diabetes and coronary heart disease. Metabolism 56 (5), 662669.

Wang, X., Zhang, J., Du, X., Song, M., Jia, C., Liu, H., 2013. Association of A561C and G98T polymorphisms in E-selectin gene with coronary artery disease: a metaanalysis. PLoS One 8 (11), e79301.

Wilson, A.G., Symons, J.A., McDowell, T.L., McDevitt, H.O., Duff, G.W., 1997. Effects of a polymorphismin the human tumor necrosis factor alpha promoter on transcriptional activation. Proc. Natl. Acad. Sci. U. S. A. 94 (7), 3195-3199.

Wu, Z., Lou, Y., Lu, L., Liu, Y., Chen, Q., Chen, X., Jin, W., 2014. Heterogeneous effect of two selectin gene polymorphisms on coronary artery disease risk: a metaanalysis. PLoS One 9 (2), e88152.
Xiang, P.X., Li, Y., Zhang, P.A., 2004. Tumour necrosis factor-alpha gene

polymorphisms and risk of coronary heart disease. Yi Chuan 26 (6), 807-810.

Xu, Q., Yuan, F., Shen, X., Wen, H., Li, W., Cheng, B., Wu, J., 2014. Polymorphisms of C242T and A640G in CYBA gene and the risk of coronary artery disease: a metaanalysis. PLoS One 29 (1), e84251.

Yang, L., Guo, X.G., Du, C.Q., Yang, J.X., Jiang, D.M., Li, B., et al., 2012. Interleukin-1 beta increases activity of human endothelial progenitor cells: involvement of PI3K-Akt signaling pathway. Inflammation 35 (4), 1242-1250. doi:http://dx.doi org/10.1007/s10753-012-9434-9.

Yusuf, S., Hawken, S., Ounpuu, S., Danas, T., Avezum, A., Lanas, F., et al., 2004. Effect of potentially modifiable risk factors associated with myocardial infarction in 52 countries (the INTERHEART study): case-control study. Lancet 364 (9438), $937-$ 952.

Zhou, L., Cai, J., Liu, G., Wei, Y., Tang, H., 2012. Associations between Interleukin-1 gene polymorphisms and coronary heart disease risk: a meta-analysis. PLoS One 7 (9), e45641. 